\title{
Risk Reduction of Healthcare Workers' Exposure to COVID-19 using Failure Mode and Effect Analysis
}

\author{
Humberto Guanche Garcell ${ }^{1}$, Farid Ahmad Sohail ${ }^{2}$, \\ Tania M Fernandez Hernandez ${ }^{1}$, Angel M Felipe Garmendia ${ }^{1}$, \\ Maylia García Santoyo ${ }^{1}$, Ariadna Villanueva Arias ${ }^{1}$ \\ ${ }^{1}$ The Cuban Hospital, Hamad Medical Corporation, Qatar \\ ${ }^{2}$ Corporate Quality Improvement \& Patient Safety, Hamad Medical Corporation, Qatar
}

Corresponding Author: Humberto Guanche Garcell

\begin{abstract}
Background: The exposure to COVID-19 by staff has a major impact on healthcare system.

Objective: identify potential failures related to the exposure of HCWs to COVID-19, evaluate the potential causes and effects, and the actions to mitigate the risk of exposure.

Methods: Members of the infection control department, quality department, nursing department, and medical administration were selected as team members to conduct the Failure Mode and Effect Analysis (FMEA). The identification of potential failure modes, causes and effects was conducted in consecutive meetings. Accordingly, were identified actions to reduce the staff exposure to COVID-19.

Results: The description of the complex process was conducted including the potential inhospital and hospital-community interaction for transmission of infection to staff. In eight areas were identified 20 potential failure modes: Hand hygiene, personal protective equipment, detection of sick staff, exposure in common areas, hiring new staff, staff living conditions, and staff knowledge, skill, and perceptions about all other infection control practices. The highest ranked priorities were identified including improper PPE use (556 points), late detection of sick staff (520 points), and poor compliance with infection control practices in common areas (436 points) respectively. The mitigation strategies focused on a wide range of actions to improve the staff education, improve practices and procedures, monitor practices and feedback to staff in a continuous quality improvement cycle.
\end{abstract}

Conclusion: Data presented provides a comprehensive evaluation of the risks and mitigation measures to prevent the staff exposure to COVID-19 conducted in a high-risk environment by a qualified FMEA team.

Keywords: failure modes and effect analysis; quality management; risk mitigation; staff exposure; COVID-19; Qatar;

\section{INTRODUCTION}

Exposure to infectious diseases by healthcare workers (HCW) constitutes a major worldwide problem magnified during the current COVID-19 pandemic. ${ }^{1}$ In the previous pandemics of other beta coronaviruses, 21\% (Severe Acute Respiratory Syndrome - SARS) and 13.5\% (Middle East Respiratory Syndrome MERS) of cases were health workers, mainly related to direct patient contact in critical care and emergency departments. ${ }^{2,3}$

The risk of health workers acquiring these infections is related to multiple factors, including organization, resources, and practices among others. ${ }^{2,3}$ The safety culture across healthcare organizations constitutes a critical issue and is not only focused on patients but also on staff safety, which achieves the highest priority in the COVID19 pandemic. ${ }^{4}$ Included in this issue is the proper communication among staff, teamwork, and the spirit of continuous learning to face the day-to-day influx of new knowledge. The leadership support could be compromised because of the 
limited resources to protect the staff, with special reference to personal protective equipment. Other resources as staff, beds, and ventilators are required but the availability could be limited because of the world demand.

A key factor linked with the risk to acquire infectious diseases in the health environment is the compliance with infection control practices, which is related to the training of medical staff, the availability of resources, and the system to monitor the practices and improve them. ${ }^{2,3}$ The continuous training of staff constitutes a challenge in the real situation of limited coverage but the proper alternatives should be identified. ${ }^{5}$ The monitoring of preventive practices has a fundamental role. First, to evaluate the compliance of infection control practices, risk behaviors, and gaps. Second, to evaluate areas of improvement and the strategies to minimize the risk of healthcare workers' exposure. It should be monitored with priority given to hand hygiene, personal protective equipment use, isolation precautions, and environmental cleaning.

Considering the increased level of risk for healthcare workers during the COVID-19 pandemic and due to the Joint Commission International requirement we decide to conduct a Failure Mode and Effect Analysis (FMEA) focused on staff exposure. ${ }^{6}$ The study aims to identify potential failures related to the exposure of HCWs to COVID-19, evaluate the potential causes and effects, and the actions to mitigate the risk of exposure.

\section{METHODS}

\section{Study setting}

The Cuban Hospital (TCH) is a member of Hamad Medical Corporation (https://www.hamad.qa/EN/Pages/default.as px) the main healthcare provider in Qatar. It is a 75-bed capacity facility providing care to the population in Western Qatar. From April 2020 as a response to the COVID-19 pandemic, the hospital capacity was expanded to 381 beds using areas previously dedicated to ambulatory services and additional tents.

\section{Team Selection}

Members of the infection control department, quality department, nursing department, and medical administration were selected as team members to conduct the FMEA, including physicians and nurses with previous experiences in quality improvement.

\section{Study population}

The study population consisted of healthcare workers from different categories, including medical and nonmedical staff, who provide care to COVID19 patients.

\section{Study design and method}

A descriptive and qualitative study was carried out in $\mathrm{TCH}$ from December 2020 to March 2021.

The FMEA team members studied the complex process of staff exposures including in the hospital as well as in the community, and their interactions. The major process steps were identified and refined in consecutive meetings, and a final process map was drafted accordingly. Subsequently were identified the failure modes related to staff exposure across the process, the potential causes, and the effects. A score of 1-10 was assigned to each identified failure mode according to the probable frequency of occurrence $(\mathrm{O})$, the probability to detect the cause (D), and the severity of the effect for staff (S). The FMEA scoring system is presented in Table 1.

The Risk Priority Number (RPN) was calculated using the following formula:

$$
R P N=O * D * S
$$

The sum of the points assigned to each failure mode in each item function constituted the Criticality Index (CI) that facilitates the prioritization of actions to reduce the staff exposure. Finally, the team members in open discussions identified corrective measure to prevent staff exposure according to the prioritized failure modes previously identified (Table 3) 
Humberto Guanche Garcell et.al. Risk reduction of healthcare workers' exposure to COVID-19 using failure mode and effect analysis.

\section{RESULTS}

The team members in the initial steps identified the transmission lines: 1) from patients to staff during the healthcare, 2) from staff to staff in the healthcare setting, 3) from staff contaminated in the healthcare environment to staff sharing the accommodation and, 4) from staff contaminated in the community to staff sharing the accommodation. These lines clarify the exposure:

- at the hospital, across all the processes from patient admission to discharge and during staff interaction including feeding, educational activities, meetings, and any other non-direct patient care activities.

- at the community, during the interaction of staff either by sharing accommodations or by others staff social contact at the community

A process map was drafted taking into consideration the previous information. (Figure 1)

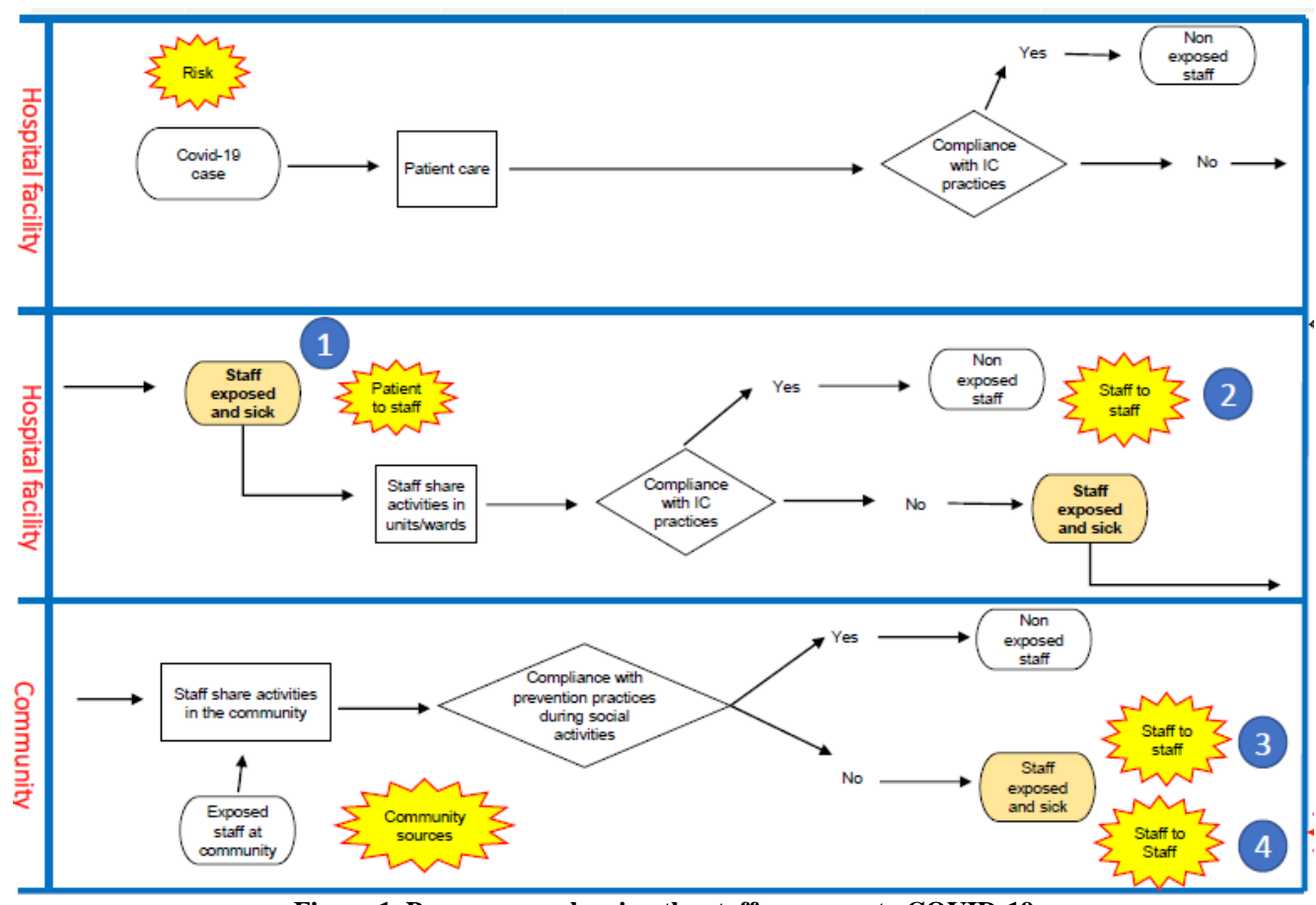

Figure 1. Process map showing the staff exposure to COVID-19

Table 1. FMEA scoring system
\begin{tabular}{|l|l|l|}
\hline $\begin{array}{l}\text { Occurrence Scoring } \\
\text { Guide }\end{array}$ & $\begin{array}{l}\text { Detectability } \\
\text { Scoring Guide }\end{array}$ & $\begin{array}{l}\text { Severity } \\
\text { Scoring Guide }\end{array}$ \\
\hline 1- unlikely to occur & $\begin{array}{l}\text { 1-3 Can be easily } \\
\text { detected at an } \\
\text { instant }\end{array}$ & $\begin{array}{l}1-3 \text { Minimal } \\
\text { impact }\end{array}$ \\
\hline 2-3 Less likely to occur & $\begin{array}{l}\text { 4-6 Can be detected } \\
\text { after several errors } \\
\text { /days }\end{array}$ & $\begin{array}{l}\text { 4-6 Moderate } \\
\text { impact }\end{array}$ \\
\hline 4-6 Likely to occur & $\begin{array}{l}\text { 7-8 Difficult to } \\
\text { detect }\end{array}$ & $\begin{array}{l}\text { 7-8 High } \\
\text { impact }\end{array}$ \\
\hline 7-8 Highly Likely & $\begin{array}{l}\text { 9-10 Impossible to } \\
\text { detect }\end{array}$ & $\begin{array}{l}\text { 9-10 } \\
\text { Catastrophic }\end{array}$ \\
\hline 9-10 Certainly & & \\
\hline
\end{tabular}

It was identified the eight areas related to the potential failure mode: Hand hygiene, personal protective equipment, detection of sick staff, exposure in common areas, hiring new staff, staff living conditions, and staff knowledge, skill, and perceptions about all other infection control practices. In these areas were identified 20 potential failure modes, and their potential causes and effects. (Table 2)

Three potential modes of failure were identified concerning hand hygiene which constituted the principal cause of infection transmission in healthcare facilities including exposure to microbial agents The availability, selection, and proper use of personal protective equipment constitute key factors related to staff exposure to COVID-19, in which six probable failure modes were identified. 


\begin{tabular}{|c|c|c|c|c|c|c|c|c|}
\hline $\begin{array}{c}\text { Item } \\
\text { Function }\end{array}$ & Potential Failure Mode & Potential Causes & Failure Effect & $\underbrace{}_{*}$ & 空 & 络 & 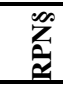 & Corrective Measures \\
\hline \multirow[t]{3}{*}{$\begin{array}{l}\text { Hand hygiene } \\
\text { (HH) }\end{array}$} & $\begin{array}{l}\text { Missed HH: hand hygiene } \\
\text { not performed at the } \\
\text { required moment }\end{array}$ & $\begin{array}{l}\text { Low level of education, and staff } \\
\text { attitude } \\
\text { Lack of manpower to regularly } \\
\text { monitor/observe HH }\end{array}$ & $\begin{array}{l}\text { Increased risk of } \\
\text { exposure to Covid-19 } \\
\text { Spread of infections }\end{array}$ & 2 & 4 & 5 & 40 & $\begin{array}{l}\text { Face to face and online } \mathrm{HH} \text { education, and other alternative } \\
\text { learning methods. } \\
\text { HH unit observers and Infection Control round assessments. } \\
\text { Add a complementary monitoring mechanism to the unit } \\
\text { observer methods. } \\
\text { Frequent feedback to staff. }\end{array}$ \\
\hline & $\begin{array}{l}\text { Wrong method of } \mathrm{HH}, \\
\text { when washing and } \\
\text { sanitizing with alcohol- } \\
\text { based hand rubs }\end{array}$ & $\begin{array}{l}\text { Low level of education, and staff } \\
\text { attitude } \\
\text { Lack of manpower to regularly } \\
\text { monitor/observe HH }\end{array}$ & $\begin{array}{l}\text { Increased risk exposure } \\
\text { to } \quad \text { Covid-19 } \\
\text { Spread of infections }\end{array}$ & 3 & 4 & 5 & 60 & $\begin{array}{l}\text { Face to face and online HH education, and other alternative } \\
\text { learning methods. } \\
\text { Add complementary monitoring mechanisms to the unit } \\
\text { observer methods. } \\
\text { Frequent feedback to staff. } \\
\text { Infection Control rounds assessments }\end{array}$ \\
\hline & $\begin{array}{l}\text { Wrong use of } \mathrm{HH} \\
\text { technique }\end{array}$ & $\begin{array}{l}\text { Low level of education, and staff } \\
\text { attitude } \\
\text { Lack of manpower to regularly } \\
\text { monitor/observe HH }\end{array}$ & $\begin{array}{l}\text { Increased risk of } \\
\text { exposure to Covid-19 } \\
\text { Spread of infections }\end{array}$ & 6 & 4 & 5 & 120 & $\begin{array}{l}\text { Face to face and online } \mathrm{HH} \text { education, and other alternative } \\
\text { learning methods. } \\
\text { Add complementary monitoring mechanisms to the unit } \\
\text { observer methods. } \\
\text { Frequent feedback to staff. } \\
\text { Infection Control rounds assessments. }\end{array}$ \\
\hline \multirow{5}{*}{$\begin{array}{l}\text { Personal } \\
\text { protective } \\
\text { equipment use } \\
\text { (PPE) }\end{array}$} & $\begin{array}{l}\text { Unavailability of different } \\
\text { respirator sizes }\end{array}$ & $\begin{array}{l}\text { Limited resources related to the } \\
\text { PPE used during the pandemic }\end{array}$ & $\begin{array}{l}\text { Increased risk exposure } \\
\text { to Covid-19 }\end{array}$ & 10 & 1 & 7 & 70 & $\begin{array}{l}\text { Enhance monitoring system and request lead times. } \\
\text { Identification of alternative strategies and educating staff on the } \\
\text { temporary solutions. }\end{array}$ \\
\hline & $\begin{array}{l}\text { Unavailability of different } \\
\text { types of required PPE }\end{array}$ & $\begin{array}{l}\text { Limited resources related to the } \\
\text { PPE used during the pandemic }\end{array}$ & $\begin{array}{l}\text { Increased risk of } \\
\text { exposure to Covid-19 }\end{array}$ & 3 & 1 & 10 & 30 & $\begin{array}{l}\text { Enhance monitoring system and request lead times. } \\
\text { Prolonged use of PPE and educating staff on the } \\
\text { recommendations for the issue. }\end{array}$ \\
\hline & $\begin{array}{l}\text { Improper donning: staff not } \\
\text { following recommended } \\
\text { method for donning }\end{array}$ & $\begin{array}{l}\text { Inadequate level of education and } \\
\text { staff attitude }\end{array}$ & $\begin{array}{l}\text { Increased risk of } \\
\text { exposure to Covid-19 }\end{array}$ & 3 & 4 & 7 & 84 & $\begin{array}{l}\text { Face to face and online } \mathrm{HH} \text { education, and other alternative } \\
\text { learning methods. } \\
\text { Units observers, Infection Control observation during daily } \\
\text { rounds. } \\
\text { Add a complementary monitoring method to the unit observer } \\
\text { methods. } \\
\text { Frequent feedback to staff. }\end{array}$ \\
\hline & $\begin{array}{l}\text { Improper doffing: staff not } \\
\text { following recommended } \\
\text { method for doffing }\end{array}$ & $\begin{array}{l}\text { Inadequate level of education, } \\
\text { staff attitude }\end{array}$ & $\begin{array}{l}\text { Increased risk of } \\
\text { exposure to Covid-19 }\end{array}$ & 3 & 4 & 9 & 108 & $\begin{array}{l}\text { Face to face and online } \mathrm{HH} \text { education, and other alternative } \\
\text { learning methods. } \\
\text { Units observers, Infection Control observation during daily } \\
\text { rounds. } \\
\text { Add a complementary monitoring method to the unit observer } \\
\text { methods. } \\
\text { Frequent feedback to staff. }\end{array}$ \\
\hline & $\begin{array}{l}\text { Wrong selection of proper } \\
\text { PPE }\end{array}$ & $\begin{array}{l}\text { Inadequate level of education } \\
\text { Low-risk perception amongst staff }\end{array}$ & $\begin{array}{l}\text { Increased risk of } \\
\text { exposure to Covid-19 }\end{array}$ & 3 & 4 & 7 & 84 & $\begin{array}{l}\text { Face to face and online } \mathrm{HH} \text { education, and other alternative } \\
\text { learning methods. } \\
\text { Units observers, Infection Control observation during daily } \\
\text { rounds. } \\
\text { Add a complementary monitoring method to the unit observer } \\
\text { methods. } \\
\text { Frequent feedback to staff. }\end{array}$ \\
\hline
\end{tabular}




\begin{tabular}{|c|c|c|c|c|c|c|c|c|}
\hline \multicolumn{9}{|c|}{ Table 2 Continued... } \\
\hline & Lack of N95 seal check & $\begin{array}{l}\text { Low level of } \begin{array}{r}\text { education } \\
\text { Low-risk perception amongst staff }\end{array}\end{array}$ & $\begin{array}{l}\text { Increased risk of } \\
\text { exposure to Covid-19 }\end{array}$ & 5 & 4 & 9 & 180 & $\begin{array}{l}\text { Staff education using face to face, online, and other learning } \\
\text { methods. } \\
\text { Unit observers, Infection Control observation during daily } \\
\text { rounds. } \\
\text { Add a complementary monitoring method to the unit observer } \\
\text { methods. } \\
\text { Frequent feedback to staff. }\end{array}$ \\
\hline \multirow[t]{3}{*}{$\begin{array}{l}\text { Detection of } \\
\text { COVID-19 } \\
\text { staff }\end{array}$} & $\begin{array}{l}\text { Late detection of COVID- } \\
19 \text { staff based on symptoms } \\
\text { and signs monitoring }\end{array}$ & Unreliable monitoring system & $\begin{array}{l}\text { Risk of transmission to } \\
\text { staff/others }\end{array}$ & 5 & 3 & 5 & 75 & 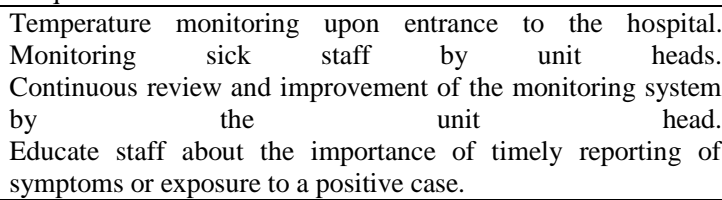 \\
\hline & & $\begin{array}{l}\text { No systematic screening of staff } \\
\text { using lab test (PCR or antigen } \\
\text { test) }\end{array}$ & $\begin{array}{l}\text { Risk of transmission to } \\
\text { staff/others }\end{array}$ & 3 & 3 & 5 & 45 & $\begin{array}{lcccc}\text { Strengthen staff } & \text { monitoring by unit } & \text { heads. } \\
\text { Implement additional system by infection control staff. }\end{array}$ \\
\hline & & $\begin{array}{l}\text { Delayed reporting of symptoms by } \\
\text { sick staff due to fear and stigma }\end{array}$ & $\begin{array}{l}\text { Risk of transmission to } \\
\text { staff/others }\end{array}$ & 5 & 8 & 10 & 400 & $\begin{array}{l}\text { Strengthen monitoring by unit heads and infection control staff } \\
\text { (face to face, virtual, poster, and reminders) } \\
\text { Educate staff on the importance of timely reporting of } \\
\text { symptoms or exposure to positive cases. } \\
\text { Feedback to unit heads and leaders. }\end{array}$ \\
\hline \multirow[t]{4}{*}{$\begin{array}{l}\text { Exposure in } \\
\text { common areas }\end{array}$} & $\begin{array}{l}\text { Social distance not } \\
\text { maintained in corridors and } \\
\text { crowded areas }\end{array}$ & $\begin{array}{l}\text { Low-risk perception, low level of } \\
\text { education, monitoring, and } \\
\text { feedback }\end{array}$ & $\begin{array}{l}\text { Risk of transmission to } \\
\text { staff/others }\end{array}$ & 4 & 5 & 10 & 200 & $\begin{array}{l}\text { Change the physical layout of staff and patient seating. } \\
\text { Change patient, staff, and utility pathways. } \\
\text { Install acrylic barriers in admin and nursing stations. } \\
\text { Strengthen monitoring by unit heads and infection control staff } \\
\text { (face to face, virtual, poster, and reminders). } \\
\text { Educate staff. } \\
\text { Give feedback to unit heads and leaders. }\end{array}$ \\
\hline & $\begin{array}{l}\text { Social distance violation in } \\
\text { tea rooms }\end{array}$ & $\begin{array}{l}\text { Low-risk perception, inadequate } \\
\text { level of education, monitoring, } \\
\text { and feedback }\end{array}$ & $\begin{array}{l}\text { Risk of transmission to } \\
\text { staff/others }\end{array}$ & 4 & 5 & 10 & 200 & $\begin{array}{l}\text { Limit the number of staff in tea rooms and meeting rooms. } \\
\text { Use video conference technology for meetings. } \\
\text { Strengthen monitoring by unit heads and infection control staff } \\
\text { (face to face, virtual, poster, and reminders). } \\
\text { Educate the staff. } \\
\text { Give feedback to unit heads and leaders. }\end{array}$ \\
\hline & $\begin{array}{l}\text { Improper cleaning and } \\
\text { disinfection } \\
\text { environmental surfaces } \\
\text { Exchange of potentially } \\
\text { contaminated items (e.g. } \\
\text { pens, patients' form) }\end{array}$ & $\begin{array}{l}\text { Lack of education, continuous } \\
\text { monitoring-feedback }\end{array}$ & $\begin{array}{l}\text { Risk of exposure to } \\
\text { Covid-19 }\end{array}$ & 2 & 3 & 3 & 18 & $\begin{array}{l}\text { Revise cleaning regime of multiple-touch and other surfaces } \\
\text { Cleaning work stations after use. } \\
\text { Strengthen monitoring by unit heads and infection control staff. } \\
\text { Educate staff. } \\
\text { Give feedback to unit heads and leaders. }\end{array}$ \\
\hline & $\begin{array}{l}\text { Improper cleaning and } \\
\text { disinfection of devices and } \\
\text { equipment }\end{array}$ & $\begin{array}{l}\text { Lack of education, continuous } \\
\text { monitoring-feedback }\end{array}$ & $\begin{array}{l}\text { Risk of exposure to } \\
\text { Covid-19 }\end{array}$ & 2 & 3 & 3 & 18 & $\begin{array}{l}\text { Revise cleaning and disinfection regime for devices and } \\
\text { equipment. } \\
\text { Disinfect equipment and working areas. } \\
\text { Strengthen monitoring by unit head and infection control staff. } \\
\text { Educate the staff. } \\
\text { Give feedback to unit heads and leaders. }\end{array}$ \\
\hline
\end{tabular}




\begin{tabular}{|c|c|c|c|c|c|c|c|c|}
\hline \multicolumn{9}{|c|}{ Table 2 Continued... } \\
\hline $\begin{array}{l}\text { Hiring new } \\
\text { staff }\end{array}$ & $\begin{array}{l}\text { Low level of knowledge } \\
\text { and skills about infection } \\
\text { control practices }\end{array}$ & $\begin{array}{l}\text { Lack of basic education in current } \\
\text { infection control practices }\end{array}$ & $\begin{array}{l}\text { Risk of exposure to } \\
\text { Covid-19 }\end{array}$ & 9 & 2 & 7 & 126 & $\begin{array}{l}\text { Staff evaluation and capacity assessment upon recruitment. } \\
\text { Face to face education during staff induction and other } \\
\text { refresher training at regular intervals. } \\
\text { Frequent monitoring of skill by unit heads and supervisors. } \\
\text { Using infection control checklists. } \\
\text { Feedback to the staff and key leaders. }\end{array}$ \\
\hline & $\begin{array}{l}\text { Long exposure to infected } \\
\text { patients during health care }\end{array}$ & Staffing availability & $\begin{array}{l}\text { Risk of exposure to } \\
\text { Covid-19 }\end{array}$ & 8 & 1 & 10 & 80 & Review schedule of staff assignment across hospital facilities. \\
\hline \multirow[t]{2}{*}{$\begin{array}{l}\text { Staff living } \\
\text { conditions }\end{array}$} & $\begin{array}{l}\text { Improper } \\
\text { accommodation }\end{array}$ & $\begin{array}{l}\text { Budget limitations, availability of } \\
\text { facilities/resources }\end{array}$ & $\begin{array}{l}\text { Staff risk of exposure } \\
\text { to Covid-19 outside the } \\
\text { hospital }\end{array}$ & 7 & 10 & 1 & 70 & $\begin{array}{l}\text { Assess the existing condition of staff accommodation. } \\
\text { Educate staff about practices to prevent exposure to Covid-19 } \\
\text { in staff hostels. }\end{array}$ \\
\hline & Sharing transportation & $\begin{array}{l}\text { Budget limitations, availability of } \\
\text { resources }\end{array}$ & $\begin{array}{l}\text { Staff risk of exposure } \\
\text { to Covid-19 outside the } \\
\text { hospital }\end{array}$ & 5 & 10 & 1 & 50 & $\begin{array}{l}\text { Monitor and evaluate the use of shared transportation and the } \\
\text { risk of staff exposure to Covid-19. } \\
\text { Continuous use of a mask when staff is onboard. } \\
\text { Provide hand sanitizers in all the buses. } \\
\text { Clean and disinfect surfaces inside staff buses. } \\
\text { Isolate COVID-19 staff soon as a case is detected. }\end{array}$ \\
\hline \multirow{4}{*}{$\begin{array}{l}\text { Staff } \\
\text { knowledge, } \\
\text { skills, and } \\
\text { perception } \\
\text { about other } \\
\text { infection } \\
\text { control } \\
\text { practices } \\
\text { (ICP) } \\
\end{array}$} & $\begin{array}{l}\text { Low compliance with } \\
\text { infection control practices }\end{array}$ & $\begin{array}{l}\text { Inadequate level of education and } \\
\text { experience }\end{array}$ & $\begin{array}{l}\text { Low compliance with } \\
\text { ICPs and ultimately } \\
\text { staff exposure to } \\
\text { Covid-19 }\end{array}$ & 3 & 5 & 10 & 150 & $\begin{array}{l}\text { Ongoing evaluation of staff competence. } \\
\text { Monitoring staff practices and feedback for improvement. } \\
\text { Implementing regular monitoring by unit head, supervisors, and } \\
\text { infection control staff and feedback to staff and key leaders }\end{array}$ \\
\hline & & Low-risk perception amongst staff & $\begin{array}{l}\text { Low compliance with } \\
\text { ICPs and ultimately } \\
\text { staff expose to Covid- } \\
19\end{array}$ & 5 & 5 & 7 & 175 & $\begin{array}{l}\text { Ongoing evaluation of staff competence. } \\
\text { Monitoring staff practices and feedback for improvement. } \\
\text { Implement regular monitoring by the unit head, supervisors, } \\
\text { and infection control staff and feedback to staff and main } \\
\text { leaders. }\end{array}$ \\
\hline & & $\begin{array}{l}\text { Inadequate manpower to properly } \\
\text { supervise and continuously } \\
\text { monitor staff performance }\end{array}$ & $\begin{array}{l}\text { Low compliance with } \\
\text { ICPs and ultimately } \\
\text { staff exposure to } \\
\text { Covid-19 }\end{array}$ & 3 & 5 & 9 & 135 & $\begin{array}{l}\text { Enhance monitoring by unit heads, supervisors, and infection } \\
\text { control staff and feedback to staff and key leaders. }\end{array}$ \\
\hline & Staff stress, burnout/fatigue & 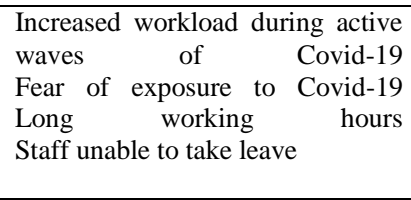 & 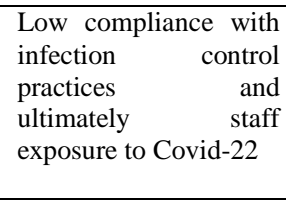 & 5 & 5 & 5 & 125 & $\begin{array}{l}\text { Regular assessment of the potential negative psychological } \\
\text { impact of working in a Covid-19 facility during the pandemic. } \\
\text { Train supervisors in identifying stress triggers amongst staff. } \\
\text { Review staff assignment in different units. } \\
\text { Arrange webinars and resilience training for staff } \\
\text { Provide mental health support using corporate services }\end{array}$ \\
\hline
\end{tabular}

* How frequent is cause likely to Occur?, $†$ How probable is Detection of cause? + How Severe is effect to the customer?, $\$$ Risk Priority \# to rank order concerns 
Humberto Guanche Garcell et.al. Risk reduction of healthcare workers' exposure to COVID-19 using failure mode and effect analysis.

Table 3. Criticality index and ranks according to potential failure mode

\begin{tabular}{|l|l|l|l|}
\hline \multicolumn{2}{|l|}{ Potential Failure Mode } & $\begin{array}{l}\text { Criticality } \\
\text { index }\end{array}$ & Ranks \\
\hline 1 & Improper Hand hygiene & 340 & 6 \\
\hline 2 & Improper PPE use & 556 & 1 \\
\hline 3 & Emergency hiring of new staff & 346 & 5 \\
\hline 4 & Improper living condition skill and & 120 & 8 \\
\hline 5 & $\begin{array}{l}\text { Improper knowledge, } \\
\text { attitude }\end{array}$ & 7 \\
\hline 6 & Negative psychological impact & 375 & 4 \\
\hline 7 & Late detection of sick staff & 520 & 2 \\
\hline 8 & $\begin{array}{l}\text { Poor compliance of infection } \\
\text { control practices in common areas }\end{array}$ & 436 & 3 \\
\hline
\end{tabular}

The early detection of sick staff plays an important role in preventing secondary transmission to patients, visitors, and other staff members. Also, the timely management of the staff sick allows the prevention and protection from adverse outcomes of COVID-19, including severe morbidity and mortality.

In the hospital, exposure includes the contact among staff and patients during the provision of care and among staff members in common areas including inpatients wards, corridors, tea rooms, cafeterias, and others. In these, the prevention of exposure could be achieved by maintaining social distance, and environmental cleaning and disinfection as fundamental practices. The team members identified the areas for staff feeding (mainly tea rooms) as high risk of transmission due to the time required for feed and the close contact without a mask. Also, during this time the room is shared by staff with different risks of exposure to COVID-19 patients. Four potential failure modes were identified related to the exposure in common areas.

The overwhelming amount of patients during the COVID-19 pandemic represents a challenge for the healthcare system and determines the need to hire new staff. The new staff should be sent to the frontline as soon as possible and probably without adequate training for prevention of the exposures. This staff received initial face-to-face training in small groups (because of the limited capacity of the venue as per regulations) and limited ongoing training in the units. In addition, the need to accommodate and transport the large quantity of staff will generate additional risks of exposure.

The COVID-19 pandemic has originated a huge and dynamic flow of knowledge on all aspects of the disease including infection prevention and control issues. Also, the pandemic has been associated with fear and stress in all the health workforce. The knowledge, skill, and perception of infection control practice by staff are fundamental for proper compliance with required infection control practices and thereby the prevention of exposure.

Having identified the potential causes and effects of the potential failure modes, in an open discussion the team members assigned a score to the occurrence, detection and severity for each potential cause. Later, risk reduction strategies were developed by identification of control measures for each potential cause.

The RPN was calculated and the criticality index presented in Table 3 show the higher ranks for the improper PPE use (556 points), late detection of sick staff (520 points), and poor compliance with infection control practices in common areas (436 points) with a lower contribution to the other failure modes.

\section{DISCUSSION}

The evaluation of potential failures related to the risk of staff exposure to COVID-19 was addressed by the FMEA team which also allowed the identification of strategies for risk mitigation.

From the early discussions, the complexity of the processes involved in the exposure of staff across all the in-hospital patient care processes and the community risks was defined because of the many challenges existed during the COVID-19 pandemic. Among other challenges, the overwhelming amount of patients, linked with the highly transmissible pattern of this virus, impacted the staff coverage and the need to hire additional staff and receive the additional support of volunteers. In consequence, the accommodation and 
transportation of these staff became a probable environment for transmission.

The well-known risk of infection transmission among healthcare workers is magnified during the current pandemic as well as the potential bidirectional transmission with the community environment. 7-11 The previous beta coronavirus pandemics (MERS and SARS) showed a predominantly nosocomial pattern with limited community transmission compared to COVID-19. ${ }^{2,3}$. Alajmi J et al describes in a descriptive study conducted in a major healthcare organization in Qatar that in $9.5 \%$ of COVID-19 cases among HCWs the source was community (family or roommate), and in additional telephonic survey highlights the exposure with a coworker.

The previous experience about staff exposure in the hospital emphasizes compliance with infection control practices as a key causal factor. ${ }^{7-11}$ Among these practices, hand hygiene, and personal protective equipment require education, monitoring, and feedback in a continuous quality improvement cycle. The education of the healthcare workforce was impacted by the COVID-19 pandemic, requiring the education events to move to e-learning, small groups, or face to face sessions in units. ${ }^{5,13}$ Regardless of the recovery from the pandemic, traditional learning should be substituted by alternative methods in which the use of technology and e-learning become the primary means of education, including the evaluation of the learning process.

In the meantime, monitoring of practice and feedback for improvement remains a challenge, and a key component of success in the new learning and quality improvement environment.

The COVID-19 pandemic has made evident the need to strengthen the monitoring system of staff with symptoms or signs of infectious disease to prevent nosocomial transmission. 14. The nosocomial transmission probably achieves the highest risk during the current pandemic, in comparison with many previous pandemics and infectious diseases outbreaks, with significant transmission risk among staff members in common areas in healthcare facilities (e.g. feeding areas) or in the staff accommodations. The early identification of sick staff (asymptomatic or symptomatic) could allow the timely prevention and control of the transmission. An important gap could be considered in the proportion of asymptomatic infections and the opportunities and possibilities of Lab tests to detect the disease in the early stages when the disease is transmitted.

The pandemic has affected the psychological wellbeing of many people globally with special reference to frontline staff, the most valuable capital of the healthcare system. Fatigue, stress, burnout, and psychological adverse effects become a barrier for the performance of staff including compliance with infection control practices. The identification of measures to prevent the adverse impact of COVID-19 on staff should include early identification of affected staff, resilience training, and mental health support services among others. ${ }^{15,16}$

The strength of risk mitigation strategies identified comes from the FMEA team's previous experience in quality management in a facility accredited by the Joint Commission International with a high score in safety culture according to an external evaluation. A limitation for the extrapolation of risks and control measures to other settings is the unique characteristics of our facility and staff. However, the general principles may be applicable in other settings to control the staff's exposure to COVID-19 and other infectious diseases.

The protection of staff constituted a priority for the healthcare system, highlighted during the COVID-19 pandemic. The data presented provides a comprehensive evaluation of the risks and mitigation measures to prevent the staff exposure to COVID-19 conducted in a highrisk environment by a qualified FMEA team. Additional action should follow the 
evaluation of the effectiveness of the mitigation program.

Disclaimer: The views presented in this manuscript are those of the authors and do not necessarily represent the views or official policy of Hamad Medical Corporation or the Ministry of Public Health, Qatar

Funding: There was no funding for this study

Ethical Issues: The study was approved at institution and inform consent was waived. The study was conducted in accordance with the Declaration of Helsinki.

ACKNOWLEDGEMENTS: We have to appreciate the contribution of the nursing leaders who provided significant inputs for the identification of the risks of staff exposure to COVID-19.

Authors' Contributions: Study design: HGG, FAS, TMFH, AMFG, AGV, MGS. Data acquisition: HGG, FAS, TMFH, AMFG, AGV, MGS. Data analysis: AAB; A HGG, FAS, TMFH, AMFG, AGV, MGS. Manuscript writing: HGG, FAS. Critical review and major scientific input: TMFH, AMFG, AGV, MGS

\section{REFERENCES}

1. Bandyopadhyay S, Baticulon RE, Kadhum M, Alser M, Ojuka DK, Badereddin Y, et al. Infection and mortality of healthcare workers worldwide from COVID-19: a systematic review. BMJ Glob Health. 2020 Dec;5(12):e003097. doi: 10.1136/bmjgh2020-003097.

2. Hui DSC, Zumla A. Severe Acute Respiratory Syndrome. Historical, Epidemiologic, and Clinical Features. Infect Dis Clin N Am [Internet]. 2019 [citado 24/03/2020];33:869-89. Disponible en: https://doi.org/10.1016/j.idc.2019.07.001.

3. Alfaraj SH, Al-Tawfiq JA, Altuwaijri TA, Alanazi M, Alzahrani N, Memish ZA. Middle East respiratory syndrome coronavirus transmission among health care workers: Implication for infection control.
Am J Infect Control. 2018;46(2):165-168. doi:10.1016/j.ajic.2017.08.010.

4. Sorra J, Gray L, Streagle Set al. AHRQ Hospital Survey on Patient Safety Culture: User's Guide. (Prepared by Westat, under Contract No.HHSA290201300003C). AHRQ Publication No. 15-0049-EF (Replaces04-0041). Rockville, MD: Agency for Healthcare Research and Quality.January 2016. https://www.ahrq.gov/sites/default/files/wys iwyg/professionals/quality-patient-

safety/patientsafetyculture/hospital/userguid e/hospcult.pdf.

5. Guanche Garcell H, Suárez Cabrera A, Márquez Furet A, González Valdés A, González Álvarez L. Componente crítico en las estrategias de atención médica, prevención y control de la COVID-19. Educación Médica Superior [Internet]. 2020 [citado 18 Jun 2021];, 34(2):[aprox. 0 p.]. Disponible

en: http://www.ems.sld.cu/index.php/ems/ar ticle/view/2385

6. Joint Commission International Accreditation Standards for Hospitals. $7^{\text {th }}$ Edition, 2020. ISBN (e-book): 978-163585-149-6.

7. Ki HK, Han SK, Son JS, Park SO. Risk of transmission via medical employees and importance of routine infection-prevention policy in a nosocomial outbreak of Middle East respiratory syndrome (MERS): a descriptive analysis from a tertiary care hospital in South Korea. BMC Pulm Med. 2019 Oct 30;19(1):190. doi: 10.1186/s12890-019-0940-5.

8. Islam MS, Rahman KM, Sun Y, Qureshi MO, Abdi I, Chughtai AA, Seale H. Current knowledge of COVID-19 and infection prevention and control strategies in healthcare settings: A global analysis. Infect Control Hosp Epidemiol. 2020 Oct;41(10): 1196-1206. doi: 10.1017/ice.2020.237.

9. Jones NK, Rivett L, Sparkes D, Forrest S, Sridhar S, Young J, et al. Effective control of SARS-CoV-2 transmission between healthcare workers during a period of diminished community prevalence of COVID-19. Elife. 2020 Jun 19;9:e59391. doi: 10.7554/eLife.59391.

10. Jin YH, Huang Q, Wang YY, Zeng XT, Luo LS, Pan ZY, et al. Perceived infection transmission routes, infection control practices, psychosocial changes, and 
Humberto Guanche Garcell et.al. Risk reduction of healthcare workers' exposure to COVID-19 using failure mode and effect analysis.

management of COVID-19 infected healthcare workers in a tertiary acute care hospital in Wuhan: a cross-sectional survey. Mil Med Res. 2020 May 11;7(1):24. doi: 10.1186/s40779-020-00254-8.

11. Chowell G, Abdirizak F, Lee S, Lee J, Jung E, Nishiura H, Viboud C. Transmission characteristics of MERS and SARS in the healthcare setting: a comparative study. BMC Med. 2015 Sep 3;13:210. doi: 10.1186/s12916-015-0450-0.

12. Alajmi J, Jeremijenko AM, Abraham JC, Alishaq M, Concepcion EG, Butt AA, Abou-Samra AB. COVID-19 infection among healthcare workers in a national healthcare system: The Qatar experience. Int J Infect Dis. 2020 Nov; 100:386-389. doi: 10.1016/j.ijid.2020.09.027.

13. Al Samaraee A. The impact of the COVID19 pandemic on medical education. $\mathrm{Br} \mathrm{J}$ Hosp Med (Lond). 2020 Jul 2;81(7):1-4. doi: 10.12968/hmed.2020.0191.

14. Moynan D, Cagney M, Dhuthaigh AN, Foley M, Salter A, Reidy N, et al. The role of healthcare staff COVID-19 screening in infection prevention \& control. J Infect. 2020 Sep;81(3):e53-e54. doi: 10.1016/j.jinf. 2020.06.057.
15. Rivett L, Sridhar S, Sparkes D, Routledge M, Jones NK, Forrest S, et al. Screening of healthcare workers for SARS-CoV-2 highlights the role of asymptomatic carriage in COVID-19 transmission. Elife. 2020 May 11;9:e58728. doi: 10.7554/eLife.58728.

16. Sagherian K, Steege LM, Cobb SJ, Cho H. Insomnia, fatigue and psychosocial wellbeing during COVID-19 pandemic: A crosssectional survey of hospital nursing staff in the United States. J Clin Nurs. 2020 Nov 20:10.1111/jocn.15566. doi: 10.1111/jocn.15566.

17. Blake $H$, Bermingham $F$, Johnson $G$, Tabner A. Mitigating the Psychological Impact of COVID-19 on Healthcare Workers: A Digital Learning Package. Int J Environ Res Public Health. 2020 Apr 26;17(9):2997. doi: 10.3390/ijerph17092997.

How to cite this article: Garcell HG, Sohail FA, Tania M Fernandez Hernandez et.al. Risk reduction of healthcare workers' exposure to COVID-19 using failure mode and effect analysis. International Journal of Research and Review. 2021; 8(7): 436-445. DOI: https://doi. org/10.52403/ijrr.20210761 